\title{
THE ENVIRONMENT ANALYSIS OF POPULATION GROWTH, UNEMPLOYMENT, AND POVERTY LEVEL IN MAESAN DISTRICT BONDOWOSO REGENCY
}

\author{
Fahmi Arif Kurnianto ${ }^{1}$, Dian Rakhmasari ${ }^{2}$, Fahrudi Ahwan Ikhsan ${ }^{3}$, Bejo Apriyanto ${ }^{4}$, \\ Elan Artono Nurdin 5 \\ 1,2,3,4,5 Department of Geography Education, University of Jember \\ Email : fahmiarif.fkip@unej.ac.id
}

Received: 10 June 2018/Revised: 7 July 2018/Accepted: 16 August 2018/Published online: 28 August 2018

\begin{abstract}
Poverty is one of the problems in the economy and environment that must be resolved immediately. The factors that influence poverty are population growth, economic growth, and unemployment. This observation aims to find out the relation of environment, population growth, economic growth, and unemployment on the level of poverty in Maesan Subdistrict, Bondowoso Regency. The data in this observation is secondary data obtained from the Central Bureau of Statistics of Bondowoso Regency. The results of this observation indicate that in comparison the variables of population growth, economic growth, and unemployment, have a significant effect on the level of poverty and environment in Maesan District, Bondowoso Regency. According to the data we obtain from the field between the influence of population growth, the economy and unemployment on average the rate of growth is slow and the people are still quite backward, still need more attention for environment effect and there are concrete actions for the development of the Maesan region. Therefore the government's encouragement is very important to promote the community in Maesan District, Bondowoso Regency.
\end{abstract}

Keywords: Population Growth, Maesan, Unemployment

\section{Introduction}

Poverty is one of the problems that often occurs in various countries, especially in Indonesia, Bondowoso Regency. The problem of poverty is not only about finance and the ability to obtain goods and services, but also concerns social, political, health and education life. In the large Indonesian dictionary $(\mathrm{KBBI})$ the word poor means people who have no wealth, are deprived, and have low income. Population growth, economic growth, unemployment and inflation are the driving factors of uncontrolled poverty. If poverty is not immediately addressed and is only a mere conversation, it will have a negative impact on the 
welfare of the nation and national development of a country. The high population growth of the earth is a problem that is quite difficult to solve completely.

With an average population growth rate of $1.8 \%$ per year, the burden of providing a variety of demands for the life of the inhabitants of the earth is very large. Until 2000 the earth's population reached around 6 billion, in 2009 the human population reached 6.4 billion (The Sustainable Scale Project, 2009) and this number tends to increase in the coming years. Therefore, data is needed as a benchmark for the occurrence of economic development. A country is said to be successful in economic development, if it is able to solve three major problems including the amount of poverty that is increasing, income levels are getting worse, and employment is not varied. The government and society must work together to balance population growth with equal distribution of population in each region, increase economic growth from all sectors which will have an impact on employment to reduce the unemployment rate, and certainly will affect the country's inflation, although not $100 \%$, at least a significant increase froms each year.

Healthy area is a condition of clean, comfortable, safe and healthy area for the community, through the improvement of a potential with integrated activities and agreed by the community, business group and government. To welcome the healthy governance can organize various activities through community empowerment and through forums facilitated by the government. Forum is a place for people to channel their aspirations and participate. Forum plays a role in determining the direction, regional development planning that integrates various aspects, so as to create a clean, comfortable, safe and healthy environment to be inhabited by its citizens. An indicator of healthy governance is a clean house, not a slum, families who keep each other clean, and a healthy lifestyle.

The condition of each environment will affect the health of the surrounding community. To improve public health it is necessary to consider the basic human needs to obtain a healthy and comfortable environment. Such as providing clean water, food, and a clean and comfortable place to live. That way can reduce poverty and slum area which is currently still quite high. As one of the factors that can affect public health, healthy governance is very important. In the order of healthy areas is expected society can maintain the cleanliness of the surrounding environment. So as not detected germs - germs that can made various diseases. With a clean, safe, comfortable and healthy area is expected to reduce the high number of infant deaths in various region. 
This study is very interested to study, Because from here could be know one of the factors causing poverty and poor environment rate in Indonesia. With the influence of a clean, healthy, safe and comfortable area design will cause a good impact. The purpose of this study is to analyze the importance of clean and healthy regional related to poverty level in Bondowoso.

\section{The Methods}

This research was conducted in March 2018 in Maesan District, Bondowoso Regency. This study used a type of survey research, where used the research method using questionnaires as an instrument for collecting data and the technique of data collection that I did was qualitative data collection techniques, by interviewing residents whose houses I visited. After interviewing from several houses of Pakuniran villagers in Maesan sub-district, and from their answers, it was able to analyze it. In taking the data, used descriptive data analysis to see the relationship between the number of population, economy, unemployment and inflation on poverty in Bondowoso District, Maesan District. To count a lot of the data reported, used Formula of Morgan below:

$$
n=\frac{\chi^{2} \cdot N \cdot P(1-P)}{(N-1) \cdot d^{2}+\chi^{2} \cdot P(1-P)}
$$

\footnotetext{
Where :

$\mathrm{n}=$ sample size

$\mathrm{N}=$ population size

$\mathrm{d}^{2}=$ acceptable for sample error

$X^{2}=$ chi square of degree of freedom

$\mathrm{P}=$ proportion of population
} 


\section{Results and Discussion}

\subsection{The Influence of Population Growth on Poverly Level}

Table 1. Population Growth in Maesan District, Bondowoso Regency

\begin{tabular}{ccc}
\hline Region & \multicolumn{2}{c}{ Gender } \\
\cline { 2 - 3 } & Male & Female \\
Rural & 4.4645 & 4.630 \\
Urban & 2.277 & 2.376 \\
\hline
\end{tabular}

Source : BPS 2017 (Statistic Agency of Indonesia)

From the data above can be seen, it turns out that the population growth in Maesan Subdistrict is quite high, but has not been matched by the existence of the Family Planning (KB) program. On the other hand, the ancient understanding of most local residents, namely "many children a lot of fortune" became one of the main triggers of Maesan District residents not to conduct Family Planning (KB) programs. In addition, the livelihoods of each family that we go to are on average many who become farm laborers and coolies, so that the income they earn is not fixed, according to the amount of work they do. From this problem a new problem arises, with a small income and a large number of families, the income is not able to meet the daily needs of the family, resulting in poverty or deprivation.

From the above problems, the government should be more attentive and more protective of its people, because then poverty which is influenced by factors such as population growth, economy, and unemployment can be overcome properly. From the community itself, they should support programs from the government that bring positive impacts to their lives. Examples such as; Family Planning Program, Counseling about family planning, etc. If a government program has a positive impact on its people and its people for the program, then the problem of population growth can be overcome properly. But when the government no longer cares about its people, and the people do not have a creative mindset, there is only the beginning of a destruction of a country or a problematic area. So all parties must be mutually sustainable and work together to complete a program that leads to welfare. 


\subsection{The Influence of Economic Growth on the Level of Poverty}

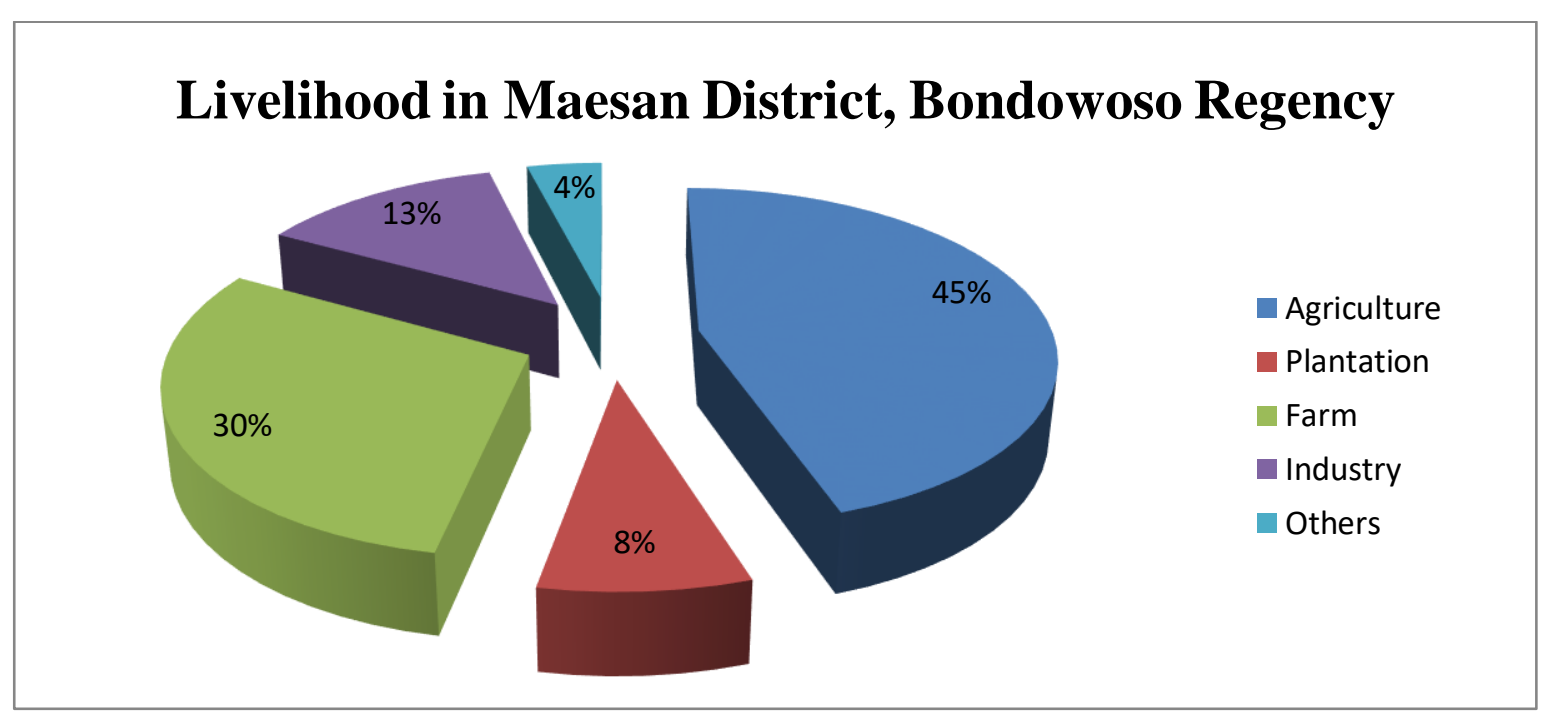

Figure 1. Livelihood in Maesan District

From the data that we have obtained in the field, economic growth in Maesan Subdistrict has experienced considerable growth, although in the economic chart it is low and the economic rate is slow. We can prove that Maesan's economy is quite developed because it can be seen from the circle table above. Maesan's livelihoods work in the field industry quite a lot even though most of his livelihoods are farmers and breeders. On average, Maesan people live in the countryside, so it is not surprising that their livelihoods are farmers and breeders. Whereas the people who live next to the highway work on the field industry on average, but not all people. While viewed from the diagram of the circle above the Maesan community is quite significant if it is still in the backward class of society. But with livelihoods as farmers and breeders that is not enough, it takes an effort that can break down the economy of the community to alleviate poverty in Maesan Subdistrict, businesses such as developing entrepreneurs from home-based small businesses, as well as the attention and assistance of the local government are needed to alleviate poverty in Maesan District. Because a country's progress can be done with mutual support between the community and the government. 


\subsection{The Influence of Unemployment on The Level of Poverty}

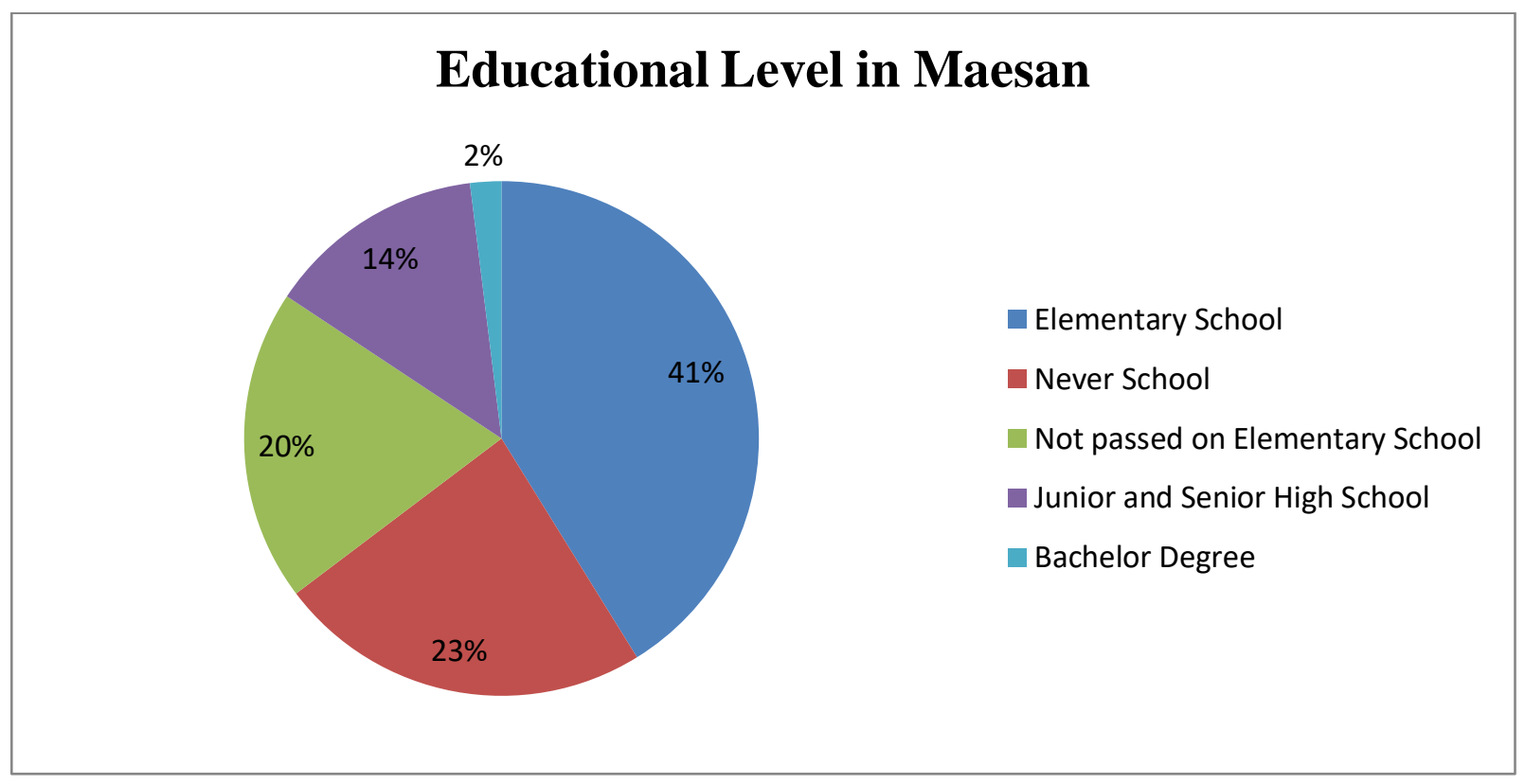

Figure 4: Educational Level in Maesan

From the above data it can be concluded that, most people in Maesan Subdistrict have a low level of education, judging from the dark Blue data circle which shows that Education graduates up to the elementary level are very dominant compared to other graduates, followed by red where people who have never gone to school are more dominant than with other graduates, then it is green, while junior and senior high school graduates are still few, let alone graduate graduates and diplomas are very low in graduates. Looking at the sample data above it can be concluded, a low level of education can cause a large number of unemployed. The evidence is found at the strata level or social status of the Maesan Subdistrict, where they are only graduates of education up to the level of Primary School Education which automatically does not have enough experience compared to high school or Diploma graduates who are far enough in comparison.

Therefore the role of the local government is needed to improve the quality of education in the Maesan Subdistrict, Bondowoso Regency, and conduct programs that can facilitate access to education there. An example of a program that can be done is a scholarship program for children from underprivileged families, scholarships for children who have achievements but from disadvantaged families. Support from the government is really needed, because an encouragement that arises from the boss is an opportunity that must be considered. Especially in the Maesan Subdistrict, Bondowoso Regency, with an average low education history, it must be changed immediately from all aspects of its life, which will 
ultimately have an impact on the mindset of its people. Because a country can be said to develop and experience growth that brings prosperity, it must be seen from the welfare of its people.

Understand and deal with poverty that is indeed interesting to listen to. In economic theory says that for break the chain of the circle of vicious kemis- can it be possible to increase security the human resources, additions investment capital, and develop technology. Through various injections then expected productivity will increase. However, in practice the problem is not easy as that. So what can be done right? Countermeasures programs poverty has been implemented in many various countries. For comparison, at United States countermeasures program poverty is directed to improve interstate economic cooperation, improve urban settlement conditions and rural, expansion of opportunities upbringing and work for young people, organizing education and training for adults, and assistance to the elderly. Addition to government programs, also circles the community is involved in helping the people poor through community organizations, church, and so on. Whereas in the country Indonesia is actually from the description above too make almost the same effort as done in the United States, maybe the level of comprehensiveness that is still needed. Handling poverty in Indonesia is still dominated by the economic sector, not yet touching other aspects like social, cultural, legal and political, even religion (Prawoto, 2009)

Poverty also make environment become not health. Slums are dirty areas, have no source of clean water, uninhabitable, unhealthy, irregular buildings, very high population density, and unqualified infrastructure facilities. Slums are usually located on the outskirts of the city, such as under a bridge. Not a few are also on the edge of the river. People who live in areas that belong to slum areas, may be often affected by the disease. The diseases that attack the bodies of the residents who live in the slums due to factors from food, clean water, and hygiene. A pregnant woman who lives in a shabby place most likely his diet is not awake. The cleanliness of his life may also be lacking. That's why the mother who is pregnant does not take care of the baby's health that is being contained. They still do the habits they always do when they are not pregnant. For example by eating unhealthy foods and often around people who are smoking.

Healthy areas are structured, away from pollution, where there is healthy food, the availability of clean water with sufficient quantities, a clean and comfortable environment, a place worthy of inhabited by humans. Healthy areas are usually rarely attacked by disease. People living in healthy areas usually live always keep the cleanliness. There may be some of them who do not maintain cleanliness so that usually their homes look 
dirty and dirty. But the majority of the population always apply cleanliness to their homes and neighborhoods.

A pregnant woman who lives in a relatively healthy area of infant mortality rate is very small. Compared to pregnant women who live in slums. Because usually pregnant women who live in healthy areas always maintain their diet, avoid pollution, and maintain cleanliness. So the chances of mother and baby exposed to the disease is very minimal. The environment is very influential on the people who live nearby. Not infrequently, usually the head of the RT or the head of the RW in a region held a consecrated work to clean up the dirt - dirt that could become a den of disease. But the hygiene of the houses depends on every homeowner. If the owner of the house is a person who always maintain cleanliness, then the house will look clean, beautiful, comfortable and healthy. But if the owner of the house is a lazy person, and does not like to keep clean, then his home will look dirty, unhealthy, bleak, and uncomfortable. All depends on each individual.

\section{Conclusion}

Based on the results of data analysis and discussion, the following conclusions can be expressed: (1) Education has a positive and significant effect on the income of poor families in Maesan Subdistrict, Bondowoso Regency, (2) The number of family dependents has a negative and significant effect on the income of poor families in Maesan District, Bondowoso Regency and (3) This type of work has a significant effect on the income of poor families in Maesan Subdistrict, Bondowoso Regency.

\section{References}

Basri, Faisal H. 1998. Indonesian Economy Ages in the XXI Century, Distortion, Opportunities and Constraints. Jakarta: Erlangga.

Boediono. 1993. Microeconomics. Yogyakarta: BPFE.

Ellies S. 1994. The Dimension of Poverty. Jakarta: Kumarien Press

Komariyah, Ani. 2013. Analysis of Several Factors Affecting Fishermen's Income: Case Study in Tembokrejo Village, Muncar District, Banyuwangi Regency. Jember: University of Jember 
Prawoto, Nano. 2005. "Understanding Poverty and Handling Strategy ". Journal of Economics and Development. Vol. 6 No. 1. FE UMY

Simanjuntak, P. 1998: Introduction to FEUI's Human Resource Economics.

Sukirno, Sadono. 1992. Introduction to Macroeconomics. Jakarta: LPFI-Press.

Widarjono, A.2013. Econometrics Theory and Application. Yogyakarta: Econisia. 